\title{
The effect of forage and forage-concentrate diets on rumen fermentation and metabolism of nutrients by the mesenteric- and portal-drained viscera in growing steers
}

\author{
BY C. J.SEAL ${ }^{1}$, D. S. PARKER ${ }^{1}$ AND P. J. AVER Y \\ ${ }^{1}$ Department of Biological and Nutritional Sciences, Faculty of Agriculture and Biological Sciences, \\ and ${ }^{2}$ Department of Mathematics and Statistics, University of Newcastle upon Tyne, \\ Newcastle upon Tyne NEI $7 R U$
}

(Received 12 March 1990-Accepted 28 June 1991)

\begin{abstract}
Growing Friesian steers chronically catheterized in the anterior mesenteric and portal veins were used to study the influence of feeding with either a forage or forage-concentrate diet on nutrient utilization by mucosal tissue. When animals were consuming the forage-concentrate diet the molar proportion of propionate in rumen fluid was significantly increased, although production rate as measured by isotope dilution was not altered. Net rates of absorption of VFA into portal blood when compared with rumen production rates underlined the extent to which metabolism within mucosal tissue modifies the propionate supply to the liver. Net glucose utilization by splanchnic tissue was shown to be significantly lower on the forage-concentrate diet. There were no effects of diet on whole-body glucose turnover or on the proportion of glucose derived from propionate. Animals fed on the forage-concentrate diet had significantly lower concentrations of circulating essential amino acids, due mainly to a reduction in branched-chain amino acid levels. There was net absorption of all amino acids by animals on both diets except for glutamate, glutamine and taurine in forage-fed animals.
\end{abstract}

Nutrient absorption: Gut tissue metabolism: Amino acid uptake: Steer

Tissues of the splanchnic bed have a considerable demand for oxygen and maintain a high metabolic activity associated with digestive and absorptive processes (Huntington \& Tyrrell, 1985; Reynolds et al. 1986). Energy demands by the visceral tissue are dependent on many factors including stage of development, lactation, metabolizable energy intake and level of nutrition (Smith \& Baldwin, 1974; Webster et al. 1975; Edelstone \& Holzman, 1981; Huntington \& Prior, 1983; Weighart et al. 1986; Burrin et al. 1989). Thus, level of intake and starvation have been shown to influence $\mathrm{Na}^{+} / \mathrm{K}^{+}$-transporting ATPase (EC 3.6.1.37)-dependent respiration in duodenal tissue of sheep in vitro (McBride $\&$ Milligan, 1985; Kelly \& McBride, 1990) and, more specifically, infusion of volatile fatty acids (VFA) into the rumen results in proliferation of the mucosal cells (Sakata \& Tamata, 1978). Sut strates available to the mucosa for oxidative metabolism in addition to arterial glucose supply vary in different regions of the gut and will be dependent on the composition of the diet. The extent to which metabolism of available nutrients by the gut tissues is influenced by diet has been the subject of a number of studies using chronically catheterized animals in which net absorption of metabolites into the portal vein has been measured (Huntington \& Prior, 1983; Huntington, 1984; James et al. 1985; Reynolds \& Huntington, $1988 a, b$; Burrin et al. 1989). The net absorption of amino acids from the gastrointestinal tract of sheep and cattle has been reported in a number of studies using animals chronically catheterized in the portal vein (Hume et al. 1972; Wolff et al. 1972; Sniffen \& Jacobsen, 1975; Huntington \& Prior, 1985). Studies in sheep in which apparent absorption of amino 
acids from the small intestine was compared with their appearance in portal blood (Tagari \& Bergman, 1978) underline the extent to which metabolism by intestinal tissues may influence amino acid availability to the liver and peripheral tissues. In addition, net portal absorption of amino acids in cattle has been shown to be influenced by both protein content of the diet and energy intake (Sniffen \& Jacobsen, 1975; Huntington \& Prior, 1985). Recent work reported by Reynolds \& Huntington (1988a), however, in which net absorption of $\alpha$ amino-nitrogen into the mesenteric and portal veins was determined, suggest that changes in the metabolism of the mucosa of the small intestine as a result of dietary manipulation may not be detected by measurements made only in the portal vein.

The objective of the present study was to investigate the influence of rumen fermentation on metabolism of energy-yielding metabolites by the gastrointestinal tissues and the net absorption of amino acids and other nutrients into the mesenteric and portal veins of growing steers fed on a forage or forage-concentrate diet. Preliminary results from part of this experiment have been published (Seal et al. 1989).

MATERIALS AND METHODS

Animals and diets

Four Friesian steers weighing between 116 and $137 \mathrm{~kg}$ at the start of the experiment were used. Chronic indwelling Silastic catheters (Dow Corning Corporation, Midland, MI, USA) were inserted in the portal vein $(1.016 \mathrm{~mm}$ i.d., $2.159 \mathrm{~mm}$ o.d.), the anterior mesenteric vein caudal to the mesenteric vein-gastrosplenic vein junction $(0.762 \mathrm{~mm}$ i.d., $1.651 \mathrm{~mm}$ o.d.) and a carotid artery $(0.762 \mathrm{~mm}$ i.d., $1.651 \mathrm{~mm}$ o.d.) (Symonds \& Baird, 1973). Two smaller infusion catheters $(0.635 \mathrm{~mm}$ i.d., $1.193 \mathrm{~mm}$ o.d.) were implanted in a distal branch of the mesenteric vein. Each animal was also fitted with a small rumen fistula $(40 \mathrm{~mm}$ i.d.) and all surgery was completed at least 3 weeks before the start of any collections. The animals were housed in individual stalls with $a d$ lib. access to drinking water and were fed on either a forage diet $(\mathrm{F})$ of dried-grass pellets or a forageconcentrate diet (F-C) prepared from the same dried grass and flaked maize in the ratio $50: 50$ (total $\mathrm{N}$ (g/kg dry matter (DM)) 31.1, 24.0; neutral-detergent fibre (g/kg DM) 551, 319; gross energy ( $\mathrm{MJ} / \mathrm{kg} \mathrm{DM}) 18 \cdot 2,18 \cdot 3$, for diet $\mathrm{F}$ and diet $\mathrm{F}-\mathrm{C}$ respectively). The experiment was of a cross-over design using two pairs of animals with $7 \mathrm{~d}$ equilibration between diets. The order in which diets were fed was balanced across the four animals which were fed hourly in twenty-four equal lots from mechanical bucket-type feeders at a fixed metabolizable energy intake calculated from Agricultural Research Council (1984) tables to give a weight gain of $700 \mathrm{~g} / \mathrm{d}$. For each dietary treatment whole-body glucose turnover rate was measured by intravenous infusion of $\left[6-{ }^{3} \mathrm{H}\right]$ glucose. Rumen propionate production rate and contribution of propionate to gluconeogenesis was determined on a separate occasion following intraruminal infusion of $\left[2-{ }^{14} \mathrm{C}\right]$ propionic acid. During each of these infusions net nutrient absorption rates and blood flow within the splanchnic bed were also determined.

\section{Infusions and sampling procedure}

Blood samples taken from catheters implanted in the portal vein represent venous blood draining the total digestive tract and thus nutrients presented to the liver from the portaldrained viscera (PDV). A part of this blood supply, sampled through the anterior mesenteric vein catheter, arises from the mesenteric-drained viscera (MDV) which represents venous blood draining the splanchnic bed up to the rumen. Contributions by the rumen to net PDV nutrient absorption can therefore be calculated by difference between PDV and MDV absorption rates. In all cases, a negative arterio-venous difference (V-A) 
or absorption rate indicates net removal of nutrient from arterial blood by the splanchnic bed; positive $\mathrm{V}-\mathrm{A}$ or absorption rate indicates net addition of nutrient by the splanchnic bed.

Blood flow. Blood flow in the portal vein and anterior mesenteric vein was determined by downstream dye dilution using p-amino hippuric acid (PAH; Katz \& Bergman, 1969). Blood samples $(15 \mathrm{ml})$ were taken hourly mid-feed from the portal vein, mesenteric vein and carotid artery during the last $6 \mathrm{~h}$ of a $7.5 \mathrm{~h}$ primed, continuous infusion of PAH into the distal mesenteric vein $(800 \mathrm{mg} \mathrm{PAH}$ priming dose, $40 \mathrm{mg} \mathrm{PAH} / \mathrm{ml}$ per min infusion rate) and treated immediately for subsequent metabolite analyses.

Measurement of whole-body glucose turnover rate. A solution of $\left[6-{ }^{3} \mathrm{H}\right] \mathrm{glucose}$ (Amersham International plc, Aylesbury, Bucks.) was prepared in autoclaved physiological saline ( $9 \mathrm{~g}$ sodium chloride/1) containing $1.5 \mu \mathrm{Ci}\left[6{ }^{3} \mathrm{H}\right] \mathrm{glucose} / \mathrm{ml}$ and $1 \mathrm{mg}$ carrier glucose $/ \mathrm{ml}$, and infused for $7.5 \mathrm{~h}$ at approximately $1.0 \mathrm{ml} / \mathrm{min}$ using a Watson Marlow Model 501 peristaltic pump (Watson Marlow Ltd, Falmouth, Cornwall) via a temporary jugular catheter inserted the previous day. Blood samples $(15 \mathrm{ml})$ taken hourly from the carotid artery into ice-cold heparinized tubes during the last $6 \mathrm{~h}$ of the infusion period were immediately centrifuged at $2500 \mathrm{rev} / \mathrm{min}$ at $4^{\circ}$ (IEC Centra-7R centrifuge; Damon/IEC Division, Needham Hts, MA, USA) and the plasma was frozen at $-20^{\circ}$ for plasma glucose specific radioactivity determinations.

Measurement of propionate metabolism. Steady-state rumen propionate specific activity was established with a $12 \mathrm{~h}$ continuous intrarumen infusion of $\left[2-{ }^{1 \mathrm{~A}} \mathrm{C}\right]$ propionic acid (Amersham International plc) in saline $(0.125 \mu \mathrm{Ci} / \mathrm{ml}$ per min, $1 \mathrm{mg}$ carrier propionic acid $/ \mathrm{ml}$ ). To ensure adequate mixing in the rumen, the isotope was infused at three sites and rumen fluid was removed from a fourth through a stainless steel filter. Rumen fluid samples $(50 \mathrm{ml})$ were taken hourly during the last $6 \mathrm{~h}$ of the infusion. Subsamples were acidified immediately with orthophosphoric acid $(200 \mathrm{ml} / \mathrm{l})$ and frozen at $-20^{\circ}$ until analysed. Carotid blood samples also taken during the last $6 \mathrm{~h}$ were treated as previously described.

\section{Analytical methods}

Whole-blood glucose concentrations were determined enzymically using a YSI 23A Glucose Analyser (Clandon Scientific Ltd, Aldershot, Hants). PAH in the supernatant fraction from deproteinized whole-blood samples (whole blood-trichloracetic acid (TCA, $100 \mathrm{~g} / 1) ; 1: 12, \mathrm{v} / \mathrm{v}$ ) was determined colorimetrically (Katz \& Bergman, 1969). Urea and ammonia concentrations were measured in the supernatant fraction from whole blood deproteinized with TCA (whole blood-TCA $(100 \mathrm{~g} / 1) ; 1: 1, \mathrm{v} / \mathrm{v}$ ) by a colorimetric method using diacetyl monoxime (Moore \& Kauffman, 1970) and enzymically by the method of Bergmeyer \& Beutler (1985) respectively. Plasma L-lactate concentrations were determined using L-lactate dehydrogenase (EC 1.1.1.27; Boehringer Mannheim test combination; Boehringer Corp. Ltd, Lewes, Sussex). 3-Hydroxybutyrate concentrations were measured in the supernatant fraction from whole blood deproteinized with perchloric acid (PCA; whole blood-0.6 M-PCA, 1:1, v/v) by autoanalyser using 3-hydroxybutyrate dehydrogenase (EC 1.1.1.30; Lloyd et al. 1978). VFA were determined in the supernatant fraction from whole blood deproteinized with PCA (whole blood-0.6 M-PCA, 1:1, v/v; $2.5 \mathrm{~mm}-2-$ methyl butyric acid internal standard). A sample of supernatant fraction $(0.5 \mathrm{ml})$ was neutralized on ice with $2 \mathrm{M}$-potassium carbonate to remove excess perchlorate. The solution was re-acidified with M-oxalic acid, centrifuged and the supernatant fraction chromatographed by gas-liquid chromatography (GLC) on a Carbopak B-DA, 4\% CW $20 \mathrm{M}$ column (Supelco Inc., Belefonte, PA, USA; $4 \mathrm{~mm} \times 2.5 \mathrm{~m}$ column, oven temperature $136^{\circ}$, injector/detector temperature $200^{\circ}, \mathrm{N}_{2}$ carrier gas flow rate $30 \mathrm{ml} / \mathrm{min}$ ). 
Rumen fluid analysis. The VFA content of rumen fluid was determined by GLC using GP $10 \% \mathrm{SP}-1200 / 1 \% \mathrm{H}_{3} \mathrm{PO}_{4}$ on $80 / 100$ Chromosorb W AW (Supelco Inc.). Rumen ammonia- $\mathrm{N}$ was determined by steam distillation of rumen fluid preserved by the addition of equal volumes of $0.2 \mathrm{~m}$-hydrochloric acid. Propionate specific activity was determined in propionate eluted from high-performance liquid chromatography (HPLC) fractionation of deproteinized rumen fluid using an Aminex HPX-87H ion-exchange column ( $4 \mathrm{~mm} \times 250 \mathrm{~mm}$; Bio-Rad Chemical Division, Richmond, CA, USA), at $50^{\circ}$ with $5 \mathrm{~mm}-$ sulphuric acid at a flow rate of $0.5 \mathrm{ml} / \mathrm{min}$. Fractions $(0.5 \mathrm{ml})$ from the column were mixed with $4.5 \mathrm{ml}$ liquid scintillant (LKB Optiphase 'Hisafe' II ; Pharmacia LKB Biotechnology, Milton Keynes, Bucks.) and counted on a Beckman LS 8100 Liquid Scintillation Counter (Beckman Instruments Inc., Irvine, CA, USA).

Analysis of glucose specific radioactivity. The level of radioactivity of plasma glucose from both $\left[6-{ }^{3} \mathrm{H}\right] \mathrm{g}$ lucose and $\left[2-{ }^{14} \mathrm{C}\right]$ propionate infusions was determined after preparing the glucose penta-acetate derivative (Jones, 1965) and counting by liquid scintillation using LKB Optiphase 'Hisafe' II as scintillant.

Amino acid analysis. Plasma samples collected during one $6 \mathrm{~h}$ sampling period from each animal on both diets were bulked before analysis. Free amino acids in the supernatant fraction from deproteinized plasma (plasma-0.6 M-PCA, $2: 1, \mathrm{v} / \mathrm{v} ; 1.0 \mathrm{~mm}-\alpha$-amino butyric acid as internal standard) were determined by reversed-phase HPLC after pre-column derivatization with phenylisothiocyanate using a Waters Pico-Tag System (Waters Chromatography Division, Millipore Corporation, Milford, MA, USA).

\section{Calculations and statistical analysis}

Rumen propionate production rate and whole-body glucose turnover rate were determined by standard isotope techniques (White et al. 1969) using the appropriate ratio of isotope infusion rate and plateau propionate or glucose specific activity (SA). No allowance for interconversion of propionate with other VFA was included. The percentage of glucose synthesized from rumen propionate, calculated by the method of Leng et al. (1967), reflects transfer of primary substrate to secondary product through all available pathways and therefore does not represent direct transfer of $\mathrm{C}$ between the two pools. The rate of blood flow at each sampling catheter tip was calculated as described by Katz \& Bergman (1969). Net nutrient absorption rates were calculated as the product of blood flow rate and blood $\mathrm{V}-\mathrm{A}$ concentration differences for the total PDV and the MDV. No correction for water absorption across the MDV and PDV was made.

Statistical analysis of the difference between means for each dietary treatment was by Student's $t$ test using Glim 3.12 (Baker \& Nelder, 1978), having allowed for any differences between animals and weighting animal means to take into account the different number of replicate observations for each animal on the two diets. For each $6 \mathrm{~h}$ sampling period, values from duplicate samples were averaged to give a single observation for each animal. Replicate observations for metabolite concentrations and net flux taken on different sampling days were averaged for each animal. Period effects were tested for but were found not to be significant; since no long-term responses were expected during the course of the experiment, period effects were therefore not fitted separately in the analysis but were included in the residual error term. As a consequence of the small number of animals available for the study there were some effects due to animal variation but these were inconsistent. Within-animal variation was always less than between-animal variation for replicate observations on each diet. Animal and diet interactions were tested for but were not significant for any variable and have not been reported. Results for nutrient concentrations and net absorption rates (Tables 3 and 4 ) include all available values from replicate sampling periods within each treatment. These measurements were obtained at 
Table 1. Volatile fatty acid (VFA) and ammonia-nitrogen contents of rumen fluid from steers fed on forage and forage-concentrate diets* and difference between diets for each metabolite

(Means of replicate observations from four animals; $3 \mathrm{df}$ )

\begin{tabular}{|c|c|c|c|c|c|}
\hline & Foraget & $\begin{array}{c}\text { Forage-- } \\
\text { concentrate }\end{array}$ & $\begin{array}{c}\text { Difference } \\
\text { between } \\
\text { diets\$ }\end{array}$ & $t$ & $\begin{array}{c}\text { Statistical } \\
\text { significance } \\
\text { of difference: } P<\end{array}$ \\
\hline Total (mM) & 167.4 & $168 \cdot 6$ & $2 \cdot 7$ & 0.22 & NS \\
\hline \multicolumn{6}{|c|}{ VFA $(\mathrm{mol} / 100 \mathrm{~mol})$} \\
\hline Acetate & $74 \cdot 9$ & $64 \cdot 6$ & $-10 \cdot 2$ & $24 \cdot 21$ & $0 \cdot 01$ \\
\hline Propionate & $16 \cdot 2$ & $22 \cdot 2$ & $6 \cdot 1$ & $7 \cdot 79$ & 0.01 \\
\hline Isobutyrate & 0.4 & 0.9 & 0.6 & 11.76 & 0.01 \\
\hline Butyrate & $7 \cdot 6$ & $9 \cdot 1$ & $1 \cdot 3$ & 0.93 & NS \\
\hline Isovalerate & $0 \cdot 4$ & $1 \cdot 2$ & $0 \cdot 9$ & $9 \cdot 81$ & $0 \cdot 01$ \\
\hline Valerate & $0 \cdot 6$ & $2 \cdot 1$ & 1.6 & $4 \cdot 78$ & $0 \cdot 05$ \\
\hline $\mathrm{NH}_{3}-\mathrm{N}(\mathrm{mg} / 1)$ & 185.2 & $90 \cdot 9$ & $-95 \cdot 2$ & $7 \cdot 32$ & 0.01 \\
\hline
\end{tabular}

NS, not significant (Student's $t$ test).

* For details of diet and feeding regimen, see p. 356.

$\dagger$ Mean value of all replicates.

$¥$ Forage-concentrate-forage; calculated value from weighted means; for details of statistical methods, see pp. $358-359$.

least twice on each animal in parallel with estimates of glucose turnover and propionate metabolism, but in some instances were made on further occasions where infusions were repeated. Results are presented as diet means averaged across all animals and replicates with an estimated difference between diets $(\mathrm{F}-\mathrm{C}-\mathrm{F})$ weighted to take into account the unequal number of replicate observations for each animal. Propionate production rates, glucose kinetics and amino acid results (Tables 2, 5 and 6) are from single measurements made on each animal and diet. In view of the small number of degrees of freedom, significant differences have been quoted up to the $10 \%$ level.

\section{RESULTS}

\section{Rumen fermentation and propionate production rate}

Details of the pattern of rumen fermentation are shown in Table 1. Although the total VFA content of rumen fluid was unaffected by dietary treatment, the molar proportions of individual VFA were significantly different when animals were fed on diet F compared with diet $\mathrm{F}-\mathrm{C}$. The proportions of propionate, isobutyrate, isovalerate and valerate were all significantly greater $(P<0.01, P<0.05$ for valerate) in diet $\mathrm{F}-\mathrm{C}$-fed animals than in diet F-fed animals, and this increase was at the expense of acetate which contributed a lower proportion to the total VFA pool in animals fed on the mixed diet $(P<0.01)$. Despite the proportion of propionate in rumen fluid rising from 0.16 to 0.22 on changing diets from $F$ to $\mathrm{F}-\mathrm{C}$, the production rate of this VFA was not significantly affected by diet.

$\mathrm{N}$ intakes $(\mathrm{g} / \mathrm{d})$ were 96 and 57 for diets $\mathrm{F}$ and $\mathrm{F}-\mathrm{C}$ respectively, and this difference in intake and the form of $\mathrm{N}$ available is reflected in the lower concentration of rumen $\mathrm{NH}_{3}$ $\mathrm{N}$ for animals fed on diet $\mathrm{F}-\mathrm{C}$ compared with diet $\mathrm{F}$-fed animals $(P<0 \cdot 01$, Table 1$)$.

\section{Glucose turnover rate and contribution of propionate to glucose-C}

Whole-body glucose turnover rate, as measured by dilution of infused $\left[6-{ }^{3} \mathrm{H}\right] \mathrm{glucose}$, averaged $2.46 \mathrm{mmol} / \mathrm{min}$ and was higher for animals fed on diet F-C compared with diet 
Table 2. Propionate production rates, glucose kinetics and difference between diets for steers fed on forage and forage-concentrate diets*

(Mean values for four animals; $3 \mathrm{df}$ )

\begin{tabular}{|c|c|c|c|c|c|}
\hline & Forage & $\begin{array}{c}\text { Forage- } \\
\text { concentrate }\end{array}$ & $\begin{array}{c}\text { Difference } \\
\text { between } \\
\text { diets }\end{array}$ & $t$ & $\begin{array}{c}\text { Statistical } \\
\text { significance } \\
\text { of difference : } P<\end{array}$ \\
\hline $\begin{array}{l}\text { Propionate } \\
\text { production rate } \\
(\mathrm{mmol} / \mathrm{min})\end{array}$ & 2.95 & $3 \cdot 30$ & 0.35 & 0.83 & NS \\
\hline $\begin{array}{l}\text { Whole-body } \\
\text { glucose turnover } \\
\text { rate }(\mathrm{mmol} / \mathrm{min})\end{array}$ & $2 \cdot 18$ & 2.74 & 0.57 & $2 \cdot 5 \mathrm{l}$ & $0 \cdot 10$ \\
\hline $\begin{array}{l}\text { Proportion of } \\
\text { glucose derived } \\
\text { from propionate }\end{array}$ & 0.51 & 0.55 & 0.04 & 0.74 & NS \\
\hline $\begin{array}{l}\text { Proportion of } \\
\text { propionate } \\
\text { converted to } \\
\text { glucose }\end{array}$ & 0.76 & 0.91 & 0.14 & $1 \cdot 34$ & NS \\
\hline
\end{tabular}

NS, not significant (Student's $t$ test).

* For details of diet and feeding regimen, see p. 356.

$\dagger$ Forage-concentrate-forage.

F-fed animals $(P<0 \cdot 10$, Table 2$)$. The contribution of propionate to glucose-C calculated from the transfer quotient during $\left[2-{ }^{14} \mathrm{C}\right]$ propionate infusion (Table 2) was unaffected by dietary treatment and showed that approximately 0.53 of whole-body glucose was derived from rumen propionate. The proportion of propionate- $\mathrm{C}$ converted to glucose averaged 0.83 across both diets and was not affected by treatment (Table 2).

\section{Whole-blood metabolite concentrations and net nutrient absorption rates}

Blood flow in the portal and mesenteric veins measured by dilution of PAH is shown in Table 4. On average, mesenteric blood flow represented 0.53 of portal blood flow. There was no significant difference in blood flow in animals fed on either diet $\mathrm{F}$ or diet $\mathrm{F}-\mathrm{C}$.

\section{Glucose}

Circulating glucose levels were significantly higher $(P<0 \cdot 05)$ in animals fed on diet $\mathrm{F}-\mathrm{C}$ compared with animals fed on diet $F$ (Table 3 ). Glucose $\mathrm{V}-\mathrm{A}$ and net absorption rates across the MDV and PDV were negative for animals fed on diet $F$, indicating net utilization of glucose by the splanchnic tissue. In contrast, $\mathrm{V}-\mathrm{A}$ for diet $\mathrm{F}-\mathrm{C}$-fed animals was positive for MDV and PDV.

\section{Lactate}

Circulating blood lactate concentrations tended to be lower for animals fed on diet $\mathrm{F}-\mathrm{C}$ than for diet F-fed animals and were significantly lower in mesenteric and portal blood in animals fed on diet $\mathrm{F}-\mathrm{C}(P<0.05$, Table 3$)$. Lactate production across the PDV of diet $\mathrm{F}-\mathrm{C}$-fed animals was significantly lower than for the diet F-fed group and, overall, animals fed on diet $\mathrm{F}-\mathrm{C}$ had an apparent net production of lactate $0.97 \mathrm{mmol} / \mathrm{min}$ lower than when fed on diet $\mathrm{F}$ alone $(P<0.05$, Table 4$)$. 
Table 3. Nutrient concentrations (mmol/l) in carotid $(C)$, mesenteric $(M)$ and portal $(P)$ blood of steers fed on forage and forage-concentrate diets* and difference between diets at each sampling site

(Mean of replicate observations from four animals for $\mathbf{C}$ and $\mathbf{M}(3 \mathrm{~d})$, three animals for $\mathbf{P}(2 \mathrm{~d} f)$ )

\begin{tabular}{|c|c|c|c|c|c|c|}
\hline Metabolite & & Forage & $\begin{array}{c}\text { Forage- } \\
\text { concentrate }\end{array}$ & $\begin{array}{l}\text { Difference } \\
\text { between } \\
\text { diets }+\end{array}$ & $t$ & $\begin{array}{c}\text { Statistical } \\
\text { significance } \\
\text { of difference : } P<\end{array}$ \\
\hline \multirow[t]{3}{*}{ Glucose } & $\mathrm{C}$ & 3.808 & $4 \cdot 244$ & $0 \cdot 468$ & 4.50 & 0.05 \\
\hline & $\mathrm{M}$ & 3.747 & $4 \cdot 325$ & 0.618 & $7 \cdot 19$ & 0.01 \\
\hline & $\mathrm{P}$ & 3.671 & $4 \cdot 362$ & 0.778 & $7 \cdot 41$ & 0.05 \\
\hline \multirow{3}{*}{ Lactate } & $\mathrm{C}$ & 0.722 & 0.635 & -0.112 & 096 & NS \\
\hline & M & 0.796 & 0.694 & $-0 \cdot 122$ & $3 \cdot 39$ & 0.05 \\
\hline & $\mathrm{P}$ & 0.810 & 0.629 & -0.169 & $5 \cdot 74$ & $0-05$ \\
\hline \multirow[t]{3}{*}{ Ammonia } & $\mathrm{C}$ & 0.213 & 0.172 & -0.039 & $2 \cdot 54$ & $0 \cdot 10$ \\
\hline & $\mathrm{M}$ & 0.480 & 0.363 & $-0 \cdot 114$ & $4 \cdot 33$ & 0.05 \\
\hline & $P$ & 0.536 & 0.369 & $-0 \cdot 165$ & 3.01 & $0 \cdot 10$ \\
\hline \multirow[t]{3}{*}{ Urea } & $\mathrm{C}$ & 3.53 & 1.71 & -1.77 & $11 \cdot 27$ & 0.01 \\
\hline & $M$ & $3 \cdot 42$ & 1.69 & -1.69 & 11.56 & 0.01 \\
\hline & $\mathrm{P}$ & 3.48 & 1.69 & $-1 \cdot 74$ & $55 \cdot 73$ & 0.001 \\
\hline \multirow[t]{3}{*}{ Acetate } & $\mathrm{C}$ & 1.13 & 1.05 & -0.08 & $1 \cdot 37$ & NS \\
\hline & M & $1 \cdot 19$ & $1 \cdot 21$ & -0.05 & $0-18$ & NS \\
\hline & $P$ & $2 \cdot 16$ & 1.95 & -0.22 & 1.27 & NS \\
\hline \multirow{3}{*}{ Propionate } & $\mathrm{C}$ & 0.03 & 0.05 & 0.05 & 1.97 & NS \\
\hline & M & 0.05 & 0.15 & 0.08 & 1.29 & NS \\
\hline & $\mathbf{P}$ & $0 \cdot 20$ & 0.27 & 0.07 & 1.91 & NS \\
\hline \multirow[t]{3}{*}{ Butyrate } & $\mathrm{C}$ & ND & & & & \\
\hline & $\mathrm{M}$ & ND & & & & \\
\hline & $\mathrm{P}$ & 0.04 & $0-03$ & -0.01 & 0.88 & NS \\
\hline \multirow[t]{3}{*}{ 3-OH-But } & $\mathrm{C}$ & 0.499 & 0.524 & 0.028 & $0-59$ & NS \\
\hline & $\mathrm{M}$ & 0.550 & 0.507 & -0.062 & $1 \cdot 17$ & NS \\
\hline & $\mathbf{P}$ & 0.642 & 0.671 & 0.032 & 0.56 & NS \\
\hline
\end{tabular}

NS, not significant (Student's $t$ test); ND, not detected; 3-OH-But, 3-hydroxybutyrate.

* For details of diets and feeding regimen, see p. 356 .

$\dagger$ Mean value of all replicates.

$\ddagger$ Forage-concentrate-forage; calculated value from weighted means; for details of statistical methods, see pp. $358-359$.

\section{$\mathrm{NH}_{3}$ and urea}

Blood ammonia and urea concentrations were significantly higher for animals fed on diet $\mathrm{F}$ than when they were fed on diet $\mathrm{F}-\mathrm{C}$ (Table 3). Net absorption rates of $\mathrm{NH}_{3}$ across the MDV and PDV were positive for all animals on both diets and were significantly higher for diet F-fed animals compared with diet F-C-fed animals $(P<0 \cdot 10$, Table 4). Urea V-A for MDV and PDV showed extraction of this nutrient by the splanchnic bed and this was not affected by dietary treatment. Net urea absorption rates across the gut tissues were also unaffected by diet.

\section{VFA and 3-hydroxybutyrate}

VFA concentrations in carotid, mesenteric and portal venous blood were unaffected by dietary treatment, although acetate absorption across the PDV was significantly lower in diet $\mathrm{F}-\mathrm{C}$-fed animals $(P<0.05$, Table 4$)$. Butyrate concentrations in all but portal samples were below reliable detection limits and were unaffected by diet $(P>0 \cdot 1)$. 3Hydroxybutyrate levels, which showed considerable variation between animals, V-A 
Table 4. Portal and mesenteric blood flow $(\mathrm{l} / \mathrm{min})$ and net nutrient absorption rates in mesenteric-drained viscera and portal-drained viscera and difference between diets for steers fed on forage and forage-concentrate diets*

(Mean for replicate observations for three animals; 2 dn

\begin{tabular}{|c|c|c|c|c|c|}
\hline & Forage $\uparrow$ & $\begin{array}{l}\text { Forage- } \\
\text { concentrate }\end{array}$ & $\begin{array}{c}\text { Difference } \\
\text { between } \\
\text { diets } \$\end{array}$ & $t$ & $\begin{array}{c}\text { Statistical } \\
\text { significance } \\
\text { of difference: } P<\end{array}$ \\
\hline \multicolumn{6}{|c|}{ Blood flow $(1 / \mathrm{min})$} \\
\hline Mesenteric & $2 \cdot 806$ & $2 \cdot 529$ & -0.286 & 0.66 & NS \\
\hline Portal & $5 \cdot 203$ & 4.946 & $-0 \cdot 263$ & $1 \cdot 04$ & NS \\
\hline \multicolumn{6}{|c|}{ Mesenteric absorption rate $(\mathrm{mmol} / \mathrm{min})$} \\
\hline Glucose & -0.159 & $0 \cdot 265$ & $0 \cdot 429$ & $2 \cdot 87$ & NS \\
\hline Lactate & $0 \cdot 017$ & $-0 \cdot 149$ & -0.085 & 0.21 & NS \\
\hline Ammonia & 0.599 & $0 \cdot 399$ & $-0 \cdot 178$ & $3 \cdot 55$ & $0 \cdot 10$ \\
\hline Urea & -0.057 & 0.135 & $0 \cdot 234$ & 0.63 & NS \\
\hline Acetate & $-0 \cdot 213$ & $0 \cdot 267$ & 0.724 & $1 \cdot 35$ & NS \\
\hline Propionate & -0.028 & $0 \cdot 275$ & 0.289 & 0.86 & NS \\
\hline Butyrate & - & - & - & - & - \\
\hline 3-OH-But & 0.076 & -0.015 & -0.073 & $1 \cdot 18$ & NS \\
\hline \multicolumn{6}{|c|}{ Portal absorption rate (mmol/min) } \\
\hline Glucose & $-0 \cdot 315$ & 0.281 & $0 \cdot 815$ & $1 \cdot 34$ & NS \\
\hline Lactate & 0.984 & 0.052 & -0.966 & 5.09 & 0.05 \\
\hline Ammonia & $1 \cdot 602$ & 0.965 & -0.745 & $3 \cdot 29$ & $0 \cdot 10$ \\
\hline Urea & $-0 \cdot 751$ & $-0 \cdot 111$ & 0.806 & $0 \cdot 84$ & NS \\
\hline Acetate & $5 \cdot 179$ & $4 \cdot 787$ & $-0 \cdot 379$ & $6 \cdot 11$ & $0-05$ \\
\hline Propionate & 0.872 & 0.982 & 0.045 & $1 \cdot 66$ & NS \\
\hline Butyrate & $0 \cdot 216$ & $0 \cdot 171$ & -0.047 & $1 \cdot 29$ & NS \\
\hline 3-OH-But & 0.602 & 0.641 & -0.029 & 0.25 & NS \\
\hline
\end{tabular}

NS, not significant (Student's $t$ test); 3-OH-But, 3-hydroxybutyrate.

* For details of diets and feeding regimen, see p. 356.

$\dagger$ Mean value of all replicates.

$\$$ Forage-concentrate - forage; calculated value from weighted means; for details of statistical methods, see pp. $358-359$.

differences and absorption rates for MDV and PDV were similarly unaffected by dietary treatment.

\section{Amino acids}

The concentrations of individual plasma free amino acids (FAA) are shown in Table 5. In peripheral blood samples from animals fed on diet $F$ there were significantly higher concentrations of valine, methionine and isoleucine $(P<0.05)$ and leucine, tryptophan and lysine $(P<0 \cdot 10)$ than those obtained when diet $\mathrm{F}-\mathrm{C}$ was given. Similarly, in mesenteric blood the concentration of branched-chain amino acids (BCAA) was significantly higher when animals were fed on diet $\mathrm{F}$ (valine, isoleucine and leucine, $P<0.05$ ). In portal blood sampled from animals on the two diets, only glycine and proline showed any difference between the two treatments; in this case the concentration of these two amino acids was significantly lower $(P<0 \cdot 10)$ when diet $\mathrm{F}$ was given compared with diet $\mathrm{F}-\mathrm{C}$.

When results for individual FAA were combined into total (TAA), essential (EAA), nonessential (NEAA) and BCAA groupings (Table 6) it was apparent that for animals fed on diet $\mathrm{F}-\mathrm{C}$ circulating levels of TAA were consistently, although not significantly, lower than those in animals fed on diet $\mathrm{F}$. This difference in TAA concentration was due to the EAA content of plasma, which was significantly lower for these animals in both carotid and 
mesenteric blood samples $(P<0 \cdot 10)$, the NEAA concentration being unaffected by dietary treatment. The major component of the change in EAA concentration was due to a reduction in BCAA in blood obtained from animals fed on diet $\mathrm{F}-\mathrm{C}$ (carotid and mesenteric $P<0 \cdot 05)$.

\section{DISCUSSION}

The objective of the current study was to establish a situation in which the simultaneous measurement of metabolism within the rumen and across the gut wall could be achieved. Although difficult, this model, which included the use of radio-labelled metabolites, gives some scope for investigation of many aspects of digestion coupled to whole-body metabolic processes.

Rates of VFA production within the rumen are dependent on dietary substrates available for fermentation and the species balance within the microbial population of the rumen to which they are presented. The main difference between animals fed on roughage diets compared with those fed on concentrate diets is the higher proportion of propionate and lower proportion of acetate among the VFA produced in animals fed on concentrates. Growing steers fed on diet $\mathrm{F}-\mathrm{C}$ in the present experiment showed this change in VFA pattern (Table 1), although the increase in propionate production rate observed was not statistically significant (Table 2). This may in part reflect the poor correlation between VFA molar proportions and measured production rates of individual acids (Sutton, 1985), and also the use of continuous feeding, which has been shown to reduce the difference in VFA fermentation patterns seen between forage and forage-concentrate diets compared with the same diets given twice daily (Yost et al. 1977). Calculated propionate production rates for the diets, based on 0.62 organic matter digestibility for diet $\mathrm{F}$ and 0.78 for diet $\mathrm{F}-\mathrm{C}$ (Fitch et al. 1989), were 2.32 and $3.19 \mathrm{~mol} / \mathrm{d} ; 0.79$ and 0.97 of measured values respectively for diet $\mathrm{F}$ - and diet $\mathrm{F}-\mathrm{C}$-fed steers.

The importance of propionate as a precursor for glucose synthesis in ruminant liver is well established. About 0.53 of whole-body glucose was derived from propionate in the present study (Table 2) and this was unaffected by diet. This value is somewhat higher than estimates reported by other workers for steers fed on forage-based diets $(0.340 .40$; Gill \& Beever, 1982; Armentano \& Young, 1983; Veenhuizen et al. 1988). The influence of propionate supply on whole-body glucose turnover rate has been investigated by several groups by either dietary manipulation or supply of exogenous propionate (Bauman et al. 1971; Van Maanen et al. 1978; Veenhuizen et al. 1988). Ulyatt et al. (1970) and Herbein et al. (1978) have suggested that when energy intakes are balanced glucose turnover rate is unaffected by diet. Although there was a slight increase in glucose turnover rate in diet F-C-fed animals $(P<0 \cdot 10$, Table 2$)$, the effects of diet on glucose kinetics in the present study are complicated by the difference in protein intakes which has been shown to affect glucose turnover (Judson \& Leng, 1968; Lindsay \& Williams, 1971). A more comprehensive study with fixed protein intakes and varying propionate supply is needed to resolve this dilemma.

Net absorption rates of VFA into the portal vein from the PDV take no account of metabolism within the gut wall of the rumen or the small intestine. The small net utilization of acetate by MDV in diet F-fed animals (Table 5), for example, suggests a requirement for this nutrient by the small intestine and has been observed by other groups (Bergman \& Wolf, 1971; Reynolds \& Huntington, 1988 b). The position of the mesenteric catheter is, however, critical to this observation, since production of acetate by large intestinal fermentation and absorption into the caecal vein may mask net utilization by anterior mesenteric tissues if the sampling catheter is sited beyond the caecal vein-mesenteric vein junction (C. J. Seal and D. S. Parker, unpublished results). Stevens \& Stettler (1966) and 
Table 5. Free amino acid concentrations ( $\mu \mathrm{mol} / l)$ in carotid $(C)$, mesenteric $(M)$ and portal $(P)$, plasma of steers fed on forage and forage-concentrate diets* and difference between diets at each sampling site

\begin{tabular}{|c|c|c|c|c|c|c|}
\hline Amino acid & & Forage & $\begin{array}{c}\text { Forage-- } \\
\text { concentrate }\end{array}$ & $\begin{array}{l}\text { Difference } \\
\text { between } \\
\text { diets }\end{array}$ & $t$ & $\begin{array}{c}\text { Statistical } \\
\text { significance } \\
\text { of difference: } P<\end{array}$ \\
\hline Asp & $\begin{array}{l}\mathrm{C} \\
\mathrm{M} \\
\mathrm{P}\end{array}$ & $\begin{array}{r}5 \\
11 \\
9\end{array}$ & $\begin{array}{r}6 \\
10 \\
8\end{array}$ & $\begin{array}{r}0 \cdot 2 \\
-1 \cdot 2 \\
-1 \cdot 4\end{array}$ & $\begin{array}{l}0.17 \\
0.58 \\
0.89\end{array}$ & $\begin{array}{l}\text { NS } \\
\text { NS } \\
\text { NS }\end{array}$ \\
\hline Glu & $\begin{array}{l}\mathrm{C} \\
\mathrm{M} \\
\mathrm{P}\end{array}$ & $\begin{array}{r}112 \\
98 \\
95\end{array}$ & $\begin{array}{l}108 \\
109 \\
120\end{array}$ & $\begin{array}{r}-4 \cdot 3 \\
10 \cdot 8 \\
24 \cdot 7\end{array}$ & $\begin{array}{l}1 \cdot 21 \\
1 \cdot 49 \\
1 \cdot 21\end{array}$ & $\begin{array}{l}\text { NS } \\
\text { NS } \\
\text { NS }\end{array}$ \\
\hline Ser & $\begin{array}{l}\mathrm{C} \\
\mathrm{M} \\
\mathrm{P}\end{array}$ & $\begin{array}{l}47 \\
81 \\
67\end{array}$ & $\begin{array}{l}44 \\
77 \\
65\end{array}$ & $\begin{array}{l}-2 \cdot 4 \\
-4 \cdot 0 \\
-1 \cdot 8\end{array}$ & $\begin{array}{l}0 \cdot 64 \\
0 \cdot 37 \\
1 \cdot 47\end{array}$ & $\begin{array}{l}\text { NS } \\
\text { NS } \\
\text { NS }\end{array}$ \\
\hline Asn & $\begin{array}{l}\mathrm{C} \\
\mathrm{M} \\
\mathrm{P}\end{array}$ & $\begin{array}{l}29 \\
65 \\
49\end{array}$ & $\begin{array}{l}32 \\
67 \\
54\end{array}$ & $\begin{array}{l}2 \cdot 8 \\
2 \cdot 2 \\
5 \cdot 7\end{array}$ & $\begin{array}{l}0 \cdot 82 \\
0 \cdot 20 \\
1.52\end{array}$ & $\begin{array}{l}\text { NS } \\
\text { NS } \\
\text { NS }\end{array}$ \\
\hline Gly & $\begin{array}{l}\mathrm{C} \\
\mathrm{M} \\
\mathrm{P}\end{array}$ & $\begin{array}{l}214 \\
286 \\
217\end{array}$ & $\begin{array}{l}246 \\
314 \\
287\end{array}$ & $\begin{array}{l}31 \cdot 8 \\
28 \cdot 0 \\
70 \cdot 2\end{array}$ & $\begin{array}{l}1 \cdot 20 \\
0 \cdot 74 \\
3 \cdot 28\end{array}$ & $\begin{array}{c}\text { NS } \\
\text { NS } \\
0 \cdot 10\end{array}$ \\
\hline Gln & $\begin{array}{l}\mathrm{C} \\
\mathrm{M} \\
\mathrm{P}\end{array}$ & $\begin{array}{r}149 \\
145 \\
91\end{array}$ & $\begin{array}{l}175 \\
198 \\
192\end{array}$ & $\begin{array}{r}29.5 \\
53 \cdot 1 \\
100 \cdot 9\end{array}$ & $\begin{array}{l}1.77 \\
3.40 \\
2.89\end{array}$ & $\begin{array}{c}\text { NS } \\
0.05 \\
\text { NS }\end{array}$ \\
\hline Tau & $\begin{array}{l}\mathrm{C} \\
\mathrm{M} \\
\mathrm{P}\end{array}$ & $\begin{array}{l}37 \\
37 \\
33\end{array}$ & $\begin{array}{l}32 \\
39 \\
41\end{array}$ & $\begin{array}{r}-4.9 \\
2 \cdot 1 \\
7 \cdot 9\end{array}$ & $\begin{array}{l}1 \cdot 04 \\
0.41 \\
2 \cdot 71\end{array}$ & $\begin{array}{l}\text { NS } \\
\text { NS } \\
\text { NS }\end{array}$ \\
\hline His & $\begin{array}{l}\mathrm{C} \\
\mathrm{M} \\
\mathrm{P}\end{array}$ & $\begin{array}{l}43 \\
52 \\
45\end{array}$ & $\begin{array}{l}45 \\
57 \\
56\end{array}$ & $\begin{array}{r}1 \cdot 9 \\
4 \cdot 7 \\
10 \cdot 3\end{array}$ & $\begin{array}{l}0.33 \\
0.82 \\
0.93\end{array}$ & $\begin{array}{l}\text { NS } \\
\text { NS } \\
\text { NS }\end{array}$ \\
\hline Cit & $\begin{array}{l}\mathrm{C} \\
\mathrm{M} \\
\mathrm{P}\end{array}$ & $\begin{array}{l}58 \\
61 \\
48\end{array}$ & $\begin{array}{l}55 \\
67 \\
46\end{array}$ & $\begin{array}{r}-2.5 \\
5.5 \\
-1.6\end{array}$ & $\begin{array}{l}0.23 \\
0.53 \\
0.06\end{array}$ & $\begin{array}{l}\text { NS } \\
\text { NS } \\
\text { NS }\end{array}$ \\
\hline Thr & $\begin{array}{l}\mathrm{C} \\
\mathrm{M} \\
\mathrm{P}\end{array}$ & $\begin{array}{l}60 \\
97 \\
78\end{array}$ & $\begin{array}{l}55 \\
88 \\
74\end{array}$ & $\begin{array}{l}-5.6 \\
-9.1 \\
-3.8\end{array}$ & $\begin{array}{l}0.62 \\
0.64 \\
0.91\end{array}$ & $\begin{array}{l}\text { NS } \\
\text { NS } \\
\text { NS }\end{array}$ \\
\hline Ala & $\begin{array}{l}\mathrm{C} \\
\mathrm{M} \\
\mathrm{P}\end{array}$ & $\begin{array}{l}173 \\
299 \\
233\end{array}$ & $\begin{array}{l}182 \\
307 \\
271\end{array}$ & $\begin{array}{r}8.6 \\
7 \cdot 3 \\
38 \cdot 6\end{array}$ & $\begin{array}{l}1.02 \\
0.20 \\
1 \cdot 12\end{array}$ & $\begin{array}{l}\text { NS } \\
\text { NS } \\
\text { NS }\end{array}$ \\
\hline Arg & $\begin{array}{l}\mathrm{C} \\
\mathrm{M} \\
\mathrm{P}\end{array}$ & $\begin{array}{l}146 \\
178 \\
163\end{array}$ & $\begin{array}{r}89 \\
124 \\
147\end{array}$ & $\begin{array}{l}-57 \cdot 0 \\
-54 \cdot 9 \\
-15.8\end{array}$ & $\begin{array}{l}1 \cdot 46 \\
1 \cdot 33 \\
0.87\end{array}$ & $\begin{array}{l}\text { NS } \\
\text { NS } \\
\text { NS }\end{array}$ \\
\hline Pro & $\begin{array}{l}\mathrm{C} \\
\mathrm{M} \\
\mathrm{P}\end{array}$ & $\begin{array}{l}63 \\
87 \\
73\end{array}$ & $\begin{array}{r}80 \\
109 \\
88\end{array}$ & $\begin{array}{l}16 \cdot 9 \\
21 \cdot 8 \\
14.8\end{array}$ & $\begin{array}{l}1.96 \\
1.42 \\
3.14\end{array}$ & $\begin{array}{c}\text { NS } \\
\text { NS } \\
0 \cdot 10\end{array}$ \\
\hline Tyr & $\begin{array}{l}\mathrm{C} \\
\mathrm{M} \\
\mathrm{P}\end{array}$ & $\begin{array}{l}23 \\
30 \\
19\end{array}$ & $\begin{array}{l}14 \\
22 \\
23\end{array}$ & $\begin{array}{r}-8.9 \\
-6.3 \\
3.8\end{array}$ & $\begin{array}{l}1.76 \\
0.80 \\
0.56\end{array}$ & $\begin{array}{l}\text { NS } \\
\text { NS } \\
\text { NS }\end{array}$ \\
\hline Val & $\begin{array}{l}\mathrm{C} \\
\mathrm{M} \\
\mathrm{P}\end{array}$ & $\begin{array}{l}508 \\
524 \\
500\end{array}$ & $\begin{array}{l}298 \\
352 \\
353\end{array}$ & $\begin{array}{l}-210 \cdot 0 \\
-172 \cdot 3 \\
-146.9\end{array}$ & $\begin{array}{l}3 \cdot 78 \\
5 \cdot 08 \\
2 \cdot 39\end{array}$ & $\begin{array}{l}0.05 \\
0.05 \\
\text { NS }\end{array}$ \\
\hline Met & $\begin{array}{l}\mathrm{C} \\
\mathrm{M} \\
\mathrm{P}\end{array}$ & $\begin{array}{l}18 \\
23 \\
24\end{array}$ & $\begin{array}{l}13 \\
29 \\
24\end{array}$ & $\begin{array}{r}-4.9 \\
5 \cdot 7 \\
-0.1\end{array}$ & $\begin{array}{l}4 \cdot 20 \\
1.21 \\
0.03\end{array}$ & $\begin{array}{l}0.05 \\
\text { NS } \\
\text { NS }\end{array}$ \\
\hline
\end{tabular}


Table 5. (cont.)

\begin{tabular}{|c|c|c|c|c|c|c|}
\hline Amino acid & & Forage & $\begin{array}{c}\text { Forage- } \\
\text { concentrate }\end{array}$ & $\begin{array}{c}\text { Difference } \\
\text { between } \\
\text { diets } \dagger\end{array}$ & $t$ & $\begin{array}{c}\text { Statistical } \\
\text { significance } \\
\text { of difference: } P<\end{array}$ \\
\hline Ile & $\begin{array}{l}\mathrm{C} \\
\mathrm{M} \\
\mathrm{P}\end{array}$ & $\begin{array}{l}193 \\
234 \\
210\end{array}$ & $\begin{array}{l}121 \\
164 \\
157\end{array}$ & $\begin{array}{l}-72 \cdot 0 \\
-69 \cdot 7 \\
-53 \cdot 4\end{array}$ & $\begin{array}{l}3 \cdot 57 \\
3 \cdot 34 \\
2 \cdot 42\end{array}$ & $\begin{array}{l}0.05 \\
0.05 \\
\text { NS }\end{array}$ \\
\hline Leu & $\begin{array}{l}\mathrm{C} \\
\mathrm{M} \\
\mathrm{P}\end{array}$ & $\begin{array}{l}275 \\
317 \\
307\end{array}$ & $\begin{array}{l}204 \\
272 \\
269\end{array}$ & $\begin{array}{l}-70 \cdot 2 \\
-44 \cdot 4 \\
-38 \cdot 0\end{array}$ & $\begin{array}{l}2 \cdot 72 \\
4 \cdot 56 \\
0.95\end{array}$ & $\begin{array}{l}0.10 \\
0.05 \\
\text { NS }\end{array}$ \\
\hline Phe & $\begin{array}{l}\mathrm{C} \\
\mathrm{M} \\
\mathrm{P}\end{array}$ & $\begin{array}{r}78 \\
162 \\
89\end{array}$ & $\begin{array}{l}69 \\
88 \\
97\end{array}$ & $\begin{array}{r}-8 \cdot 7 \\
-74 \cdot 3 \\
8 \cdot 3\end{array}$ & $\begin{array}{l}0 \cdot 70 \\
1 \cdot 20 \\
0 \cdot 36\end{array}$ & $\begin{array}{l}\text { NS } \\
\text { NS } \\
\text { NS }\end{array}$ \\
\hline Trp & $\begin{array}{l}\mathrm{C} \\
\mathrm{M} \\
\mathrm{P}\end{array}$ & $\begin{array}{r}7 \\
30 \\
7\end{array}$ & $\begin{array}{l}5 \\
7 \\
9\end{array}$ & $\begin{array}{r}-2 \cdot 1 \\
-22 \cdot 9 \\
1 \cdot 3\end{array}$ & $\begin{array}{l}2.55 \\
1 \cdot 15 \\
0.29\end{array}$ & $\begin{array}{l}0 \cdot 10 \\
\text { NS } \\
\text { NS }\end{array}$ \\
\hline Orn & $\begin{array}{l}\mathrm{C} \\
\mathrm{M} \\
\mathrm{P}\end{array}$ & $\begin{array}{l}88 \\
91 \\
81\end{array}$ & $\begin{array}{l}71 \\
85 \\
85\end{array}$ & $\begin{array}{r}-17 \cdot 6 \\
-6 \cdot 3 \\
4 \cdot 2\end{array}$ & $\begin{array}{l}0.97 \\
0.52 \\
0.77\end{array}$ & $\begin{array}{l}\text { NS } \\
\text { NS } \\
\text { NS }\end{array}$ \\
\hline Lys & $\begin{array}{l}\mathrm{C} \\
\mathrm{M} \\
\mathrm{P}\end{array}$ & $\begin{array}{l}116 \\
166 \\
138 \\
\end{array}$ & $\begin{array}{r}81 \\
132 \\
132 \\
\end{array}$ & $\begin{array}{r}-35 \cdot 5 \\
-33 \cdot 8 \\
-6 \cdot 2 \\
\end{array}$ & $\begin{array}{l}2 \cdot 49 \\
1 \cdot 46 \\
0 \cdot 25 \\
\end{array}$ & $\begin{array}{l}0 \cdot 10 \\
\text { NS } \\
\text { NS }\end{array}$ \\
\hline
\end{tabular}

NS, not significant (Student's $t$ test).

* For details of diet and feeding regimen, see p. 356.

$\uparrow$ Forage-concentrate-forage.

Bergman \& Wolff (1971) calculated that $0 \cdot 3-0 \cdot 45$ of the acetate produced in the rumen was metabolized in the rumen wall, and that the proportions of propionate and butyrate metabolized were higher at 0.6 and 0.9 , representing a considerable loss of fermentable energy to productive tissues of the animal. Weekes \& Webster (1975) showed that between 0.3 and 0.55 of rumen propionate did not appear in the portal vein of sheep and that this was unaffected by different propionate infusion rates into the rumen. The acetate:propionate ratio in rumen fluid for diet F-fed animals was 4.6:1 and fell to $2 \cdot 9: 1$ in diet F-C-fed animals. However, the ratio for VFA in portal blood was much higher at 10.8:1 and 7.2:1 for diet $\mathrm{F}$ - and diet $\mathrm{F}-\mathrm{C}$-fed animals respectively. This may be due to either differences in the efficiencies of absorption of the two VFA across the rumen epithelium or differential metabolism of the VFA by the gut tissue. Propionate arriving at the liver represented only $0 \cdot 30$ of the corresponding rumen propionate production rate for the two diets. Similar calculations based on calculated acetate production rates would suggest that for these animals only 0.48 (diet F) and 0.52 (diet F-C) of acetate production in the rumen could be accounted for by acetate arriving at the liver from PDV. The significant quantity of 3hydroxybutyrate arising from PDV further emphasizes the importance of the rumen wall in modifying the supply of fermentation end-products to the liver. VFA produced in the rumen and large intestine and glucose absorbed in the small intestine provide additional energy sources which are highly dependent on the extent of fermentation in the rumen and subsequent digestion of carbohydrate along the digestive tract. Net glucose utilization by the MDV and PDV in steers fed on diet $\mathrm{F}$ in the present experiment, in contrast to net glucose production in diet F-C-fed animals, is consistent with data from forage-fed ruminants in other studies (Huntington, 1984; Janes et al. 1985; Reynolds \& Huntington, 
Table 6. Total (TAA), essential (EAA), non-essential (NEAA) and branched-chain (BCAA) amino acid $(A A)$ concentrations, net absorption rates in mesenteric $(M)$ - and portal $(P)$ drained viscera, and difference between diets for steers fed on forage or forage concentrate diets*

(Mean values of four animals for $\mathrm{C}$ and M AA concentrations $(3 \mathrm{df})$ and three animals for P AA concentrations and net absorption rates $(2 \mathrm{df})$ )

\begin{tabular}{|c|c|c|c|c|c|c|}
\hline & & Forage & $\begin{array}{l}\text { Forage- } \\
\text { concentrate }\end{array}$ & $\begin{array}{c}\text { Difference } \\
\text { between } \\
\text { diets } \dagger\end{array}$ & $t$ & $\begin{array}{c}\text { Statistical } \\
\text { significance } \\
\text { of difference: } P<\end{array}$ \\
\hline \multicolumn{7}{|c|}{$\begin{array}{l}\text { AA concentration } \\
(\mu \mathrm{mol} / \mathrm{l})\end{array}$} \\
\hline \multirow[t]{3}{*}{ TAA } & $\mathrm{C}$ & 2443 & 2024 & -419 & 1.43 & NS \\
\hline & $\mathrm{M}$ & 3074 & 2716 & -358 & $1 \cdot 16$ & NS \\
\hline & $\mathrm{P}$ & 2577 & 2598 & 22 & 0.07 & NS \\
\hline \multirow[t]{3}{*}{ EAA } & $\mathrm{C}$ & 1443 & 979 & -464 & 2.62 & 0.10 \\
\hline & $\mathrm{M}$ & 1784 & 1313 & -471 & $2 \cdot 63$ & $0 \cdot 10$ \\
\hline & $\mathrm{P}$ & 1562 & 1318 & -244 & $1 \cdot 19$ & NS \\
\hline \multirow[t]{3}{*}{ NEAA } & $\mathrm{C}$ & 1000 & 1045 & 45 & 0.81 & NS \\
\hline & $\mathrm{M}$ & 1290 & 1402 & 113 & 0.85 & NS \\
\hline & $\mathrm{P}$ & 1014 & 1280 & 265 & $2 \cdot 13$ & NS \\
\hline \multirow[t]{3}{*}{ BCAA } & $\mathrm{C}$ & 976 & 623 & -352 & 3.48 & 0.05 \\
\hline & $\mathrm{M}$ & 1075 & 788 & -286 & $4 \cdot 76$ & 0.05 \\
\hline & $\mathrm{P}$ & 1017 & 779 & -238 & 1.94 & NS \\
\hline \multicolumn{7}{|c|}{$\begin{array}{l}\text { Net absorption rates } \\
(\mu \mathrm{mol} / \mathrm{min})\end{array}$} \\
\hline \multirow[t]{2}{*}{ TAA } & $\mathbf{M}$ & 1033 & 744 & -289 & 1.41 & NS \\
\hline & $\mathrm{P}$ & 951 & 1601 & 650 & $0 \cdot 70$ & NS \\
\hline \multirow[t]{2}{*}{ EAA } & $\mathrm{M}$ & 611 & 383 & -228 & $1 \cdot 23$ & NS \\
\hline & $\mathrm{P}$ & 732 & 868 & 136 & $0 \cdot 26$ & NS \\
\hline \multirow[t]{2}{*}{ NEAA } & $\mathrm{M}$ & 422 & 361 & -61 & 0.63 & NS \\
\hline & $\mathrm{P}$ & 218 & 732 & 514 & $1 \cdot 26$ & NS \\
\hline \multirow[t]{2}{*}{ BCAA } & M & 89 & 184 & 96 & 0.49 & NS \\
\hline & $\mathrm{P}$ & 359 & 415 & 56 & $0 \cdot 19$ & NS \\
\hline
\end{tabular}

NS, not significant (Student's $t$ test).

* For details of diet and feeding regimen, see p. 356.

$\dagger$ Forage-concentrate-forage.

1988a). Net glucose utilization by rumen tissue in diet F-fed animals was $0.16 \mathrm{mmol} / \mathrm{min}$. In animals fed on diet $\mathrm{F}-\mathrm{C}$ this was reduced to $0.02 \mathrm{mmol} / \mathrm{min}$. Janes et al. (1985) and Reynolds \& Huntington (1988a) also demonstrated net glucose absorption by MDV of concentrate-fed animals and the latter group similarly noted a reduction in total net PDV glucose use in concentrate- rather than forage-fed animals.

Net lactate flux across tissues of the MDV was not affected by dietary treatment (Table 4). In contrast, there was significantly greater lactate production across the PDV for animals fed on diet $\mathrm{F}$ compared with diet $\mathrm{F}-\mathrm{C}(P<0.05)$, Table 4$)$. The proportion of lactate produced by the PDV derived from absorbed lactate or gut wall metabolism of glucose and propionate is not known, although changes in glucose utilization by different regions of the intestine are likely to alter the balance of lactate production from the different substrates available at each tissue site.

Decreased $\mathrm{NH}_{3}$ absorption by MDV and PDV (Table 5) in animals fed on diet F-C may 
be attributed to the lower $\mathrm{N}$ intake in these animals and the reduction in soluble $\mathrm{N}$ sources available in the rumen although, on average for both diets, 0.39 of total PDV $\mathrm{NH}_{3}$ absorption arose from the MDV. Urea extraction from arterial blood by the PDV is a significant proportion of total $\mathrm{N}$ removal by the splanchnic bed (Huntington, 1986). Table 4 shows extraction of urea by MDV and PDV in animals fed on both diets, and that this appeared to be greater for diet F-fed compared with diet F-C-fed animals. Although this was not statistically significant, the observation is in agreement with that of Huntington (1988) who demonstrated a similar response in beef steers fed on either lucerne (Medicago sativa) hay or a diet containing $800 \mathrm{~g}$ cracked maize $/ \mathrm{kg}$.

The diets used in the present experiment were designed to be isoenergetic and were fed at a level to give a weight gain of $700 \mathrm{~g} / \mathrm{d}$ (Agricultural Research Council, 1984). The difference in $\mathrm{N}$ content of the two diets did, however, result in a higher $\mathrm{N}$ intake for animals when on diet $\mathrm{F}-\mathrm{C}(96 \mathrm{v} .57 \mathrm{~g} \mathrm{~N} / \mathrm{D})$. Although in general an increase in $\mathrm{N}$ intake has been shown to result in elevated plasma amino acid levels in peripheral blood (Schelling et al. 1967; Bergen, 1979), other studies have shown only minor variations in circulating concentrations as a consequence of dietary change (Prior et al. 1981). A comparison of the concentrations of individual amino acids in peripheral blood between animals on the two diets in the present study (Table 5) showed that there was a significant reduction in those for valine, methionine and isoleucine $(P<0.05)$ and leucine, tryptophan and lysine $(P<$ $0 \cdot 1)$ in animals fed on diet $\mathrm{F}-\mathrm{C}$, and this was reflected in a significant reduction in the EAA $(P<0.1)$ and BCAA $(P<0.05)$ groups when this diet was given. The decreases in concentration of certain of the BCAA were similar to those reported by Mercer \& Miller (1982) following intraruminal infusion of a mixture of VFA in sheep potentially increasing energy availability to peripheral tissues. This is in contrast to the present experiment in which the dietary change resulted in a shift in fermentation pattern in the rumen without any variation in overall VFA concentration (Table 1).

On both diets, concentrations of amino acids in mesenteric and portal blood were consistently higher than in carotid samples, indicating net absorption across the intestinal wall, apart from glutamate, glutamine and taurine which showed a negative $\mathrm{V}$-A difference across the gut in animals fed on diet $\mathrm{F}$. Comparison of net absorption rates determined in the mesenteric and portal veins showed that there was a consistent increase in these values between mesenteric and portal blood in diet F-C-fed animals. Net absorption rates do not provide an absolute measure of metabolite absorption, the value reflecting the overall effect of uptake and metabolism within the tissues. An increase in apparent net uptake of amino acids into portal blood relative to that in mesenteric samples may be a result of lower utilization of amino acids by the mucosal tissues of the forestomachs when compared with that of the small intestine. An alternative to this proposal would be that FAA released as a result of proteolysis of dietary protein and microbial cells within the rumen (Mangan, 1972; Broderick \& Wallace, 1988) were absorbed directly across the rumen wall. It is of interest that in the former study accumulation of valine, isoleucine, leucine and lysine was recorded in rumen fluid and these amino acids were quantitatively the major components of the increase in net portal absorption.

Comparison of the net disappearance of amino acids from the gastrointestinal tract with their net appearance in portal blood of sheep (Tagari \& Bergman, 1978) has underlined the importance of mucosal tissue metabolism in modifying amino acid availability to the animal. The importance of both glutamate and glutamine in intestinal tissue metabolism is apparent from the negative net portal absorption data reported in sheep (Heitman \& Bergman, 1978) and cattle (Huntington \& Prior, 1985; Wilton, 1990). These two amino acids have been shown to be the major components of energy utilization by the gastrointestinal mucosa of the rat (Windmueller \& Spaeth, 1978, 1980). In the present 
experiment net utilization of both glutamine and glutamate by the PDV was apparent in animals fed on diet $\mathrm{F}$. On diet $\mathrm{F}-\mathrm{C}$, however, net absorption of glutamine and glutamate occurred and there was a significant difference $(P<0.05)$ between the values for glutamine in the mesenteric vein for the two diets, underlining the shift in tissue metabolism of these two amino acids as a result of dietary change. A similar change in glutamine utilization by the PDV in steers transferred from a forage to a concentrate diet (Reynolds \& Huntington, $1988 a$ ) provides further evidence that tissue metabolite utilization alters in these contrasting dietary situations. Net portal appearance of both glutamine and glutamate reported by Prior et al. (1981) in their studies with cattle was in contrast to studies with sheep fed on the same diets, where net utilization of the amino acids was recorded, suggesting that in addition to dietary effects there may be species differences in tissue metabolite requirements.

Although only measured over a relatively short period (4 weeks), weight gain by steers on diet $\mathrm{F}-\mathrm{C}$ was higher than when diet $\mathrm{F}$ was given, despite their having a lower $\mathrm{N}$ intake. This reduced response on the forage-based diet might be expected from previous studies in which the effects of protein supplementation of forage diets has been studied (see Beever \& Siddons, 1985). Inclusion of maize with the dried grass on a 50:50 basis resulted in a shift in rumen fermentation pattern and a reduction in both urea concentration and that of circulating amino acids, when compared with diet $\mathrm{F}$. It is also apparent that manipulation of dietary intake influences intestinal metabolism such that there may be reduced utilization of glutamine and glutamate. The mechanism by which this occurs and its implications for portal amino acid supply merits further study.

The authors acknowledge the skilled technical assistance of Ms H. Mason in undertaking the amino acid analyses and Mr B. Brown and Mr D. Smith for their excellent care of the animals used in this study.

This work was funded through an AFRC link research programme with the Institute of Grassland and Environmental Research, Hurley and the University of Reading.

\section{REFERENCES}

Agricultural Research Council (1984). The Nutrient Requirements of Ruminant Livestock, Suppl no. 1. Slough: Commonwealth Agricultural Bureaux.

Armentano, L. E. \& Young, J. W. (1983). Production and metabolism of volatile fatty acids, glucose and $\mathrm{CO}_{2}$ in steers and the effects of monensin on volatile fatty acid kinetics. Journal of Nutrition 113, 1265-1277.

Baker, R. J. \& Nelder, J. A. (1978). GLM Systems Release 3. Oxford: Numerical Algorithms Group.

Bauman, D. E., Davis, C. L. \& Bucholz, H. F. (1971). Propionate production in the rumen of cows fed either a control or high-grain, low-fiber diet. Journal of Dairy Science 54, 1282-1287.

Beever, D. E. \& Siddons, R. C. (1985). Digestion and metabolism in the growing ruminant. In Control of Digestion and Metabolism in Ruminants, pp. 479-497 [L. P. Milligan, W. L. Grovum and A. Dobson, editors]. Englewood Cliffs, NJ : Prentice-Hall.

Bergen, W. G. (1979). Free amino acids in blood of ruminants. Physiological and nutritional regulation. Journal of Animal Science 49, 1577-1589.

Bergman, E. N. \& Wolff, J. E. (1971). Metabolism of volatile fatty acids by liver and portal-drained viscera in sheep. American Journal of Physiology 221, 586-592.

Bergmeyer, H. U. \& Beutler, H. O. (1985). Ammonia. In Methods of Enzymatic Analysis, vol. 8, pp. 454461 [H. U. Bergmeyer, editor]. Weinheim, Germany: V. C. H. Verlagsgesellschaft.

Broderick, G. A. \& Wallace, R. J. (1988). Effects of dietary nitrogen source on concentrations of ammonia, free amino acids and fluorescamine-reactive peptides in the sheep rumen. Journal of Animal Science 66, 2233-2238.

Burrin, D. G., Ferrell, C. L., Eisemann, J. H., Britton, R. A. \& Nieraber, J. A. (1989). Effect of level of nutrition on splanchnic blood flow and oxygen consumption in sheep. British Journal of Nutrition 62, 23-34.

Edelstone, D. I. \& Holzman, I. R. (1981). Gastrointestinal tract $\mathrm{O}_{2}$ uptake and regional blood flow during digestion in conscious newborn lambs. American Journal of Physiology 241, G289-G293.

Fitch, N. A., Gill, M., Lomax, M. A. \& Beever, D. E. (1989). Nitrogen and glucose metabolism by the liver of forage-and forage-concentrate-fed cattle. Proceedings of the Nutrition Society 48, 76A.

Gill, M. \& Beever, D. E. (1982). The effect of protein supplementation on digestion and glucose metabolism in young cattle fed silage. British Journal of Nutrition 48, 37-47. 
Heitman, R. N. \& Bergman, E. N. (1978). Glutamine metabolism, interorgan transport and glucogenicity in the sheep. American Journal of Physiology 234, E197-E203.

Herbein, J. H., Van Maanen, R. W., McGilliard, A. D. \& Young, J. W. (1978). Rumen propionate and blood glucose kinetics in growing cattle fed isoenergetic diets. Journal of Nutrition 108, 994-1001.

Hume, I. D., Jacobson, D. R. \& Mitchell, G. E. Jr. (1972), Quantitative studies on amino acid absorption in sheep. Journal of Nutrition 102, 495-506.

Huntington, G. B. (1984). Net absorption of glucose and nitrogenous compounds in lactating Holstein cows. Journal of Dairy Science 67, 1919-1927.

Huntington, G. B. (1986). Uptake and transport of nonprotein nitrogen by the ruminant gut. Federation Proceedings 45, 2272-2276.

Huntington, G. B. (1988). Hepatic urea synthesis and site and rate of urea removal from blood of beef steers fed Alfalfa hay or a high concentrate diet. Canadian Journal of Animal Science 69, 215-223.

Huntington, G. B. \& Prior, R. L. (1983). Digestion and absorption of nutrients by beef heifers fed a high concentrate diet. Journal of Nutrition 113, 2280-2288.

Huntington, G. B. \& Prior, R. L. (1985). Net absorption of amino acids by portal-drained viscera and hind half of beef cattle fed a high concentrate diet. Journal of Animal Science 60, 1491-1499.

Huntington, G. B. \& Tyrrell, H. F. (1985). Oxygen consumption by portal-drained viscera of cattle: comparison of analytical methods and relationship to whole-body oxygen consumption. Journal of Dairy Science 68, 2727-2731.

Janes, A. N., Weekes, T. E. C. \& Armstrong, D. G. (1985). Absorption and metabolism of glucose by the mesenteric-drained viscera of sheep fed on dried-grass or ground, maize-based diets. British Journal of Nutrition 54, 449-458.

Jones, G. B. (1965). Determination of the specific activity of labeled blood glucose by liquid scintillation using glucose pentaacetate. Analytical Biochemistry 12, 249-258.

Judson, G. J. \& Leng, R. A. (1968). Effect of diet on glucose synthesis in sheep. Proceedings of the Australian Society of Animal Production 7, 354-358.

Katz, M. L. \& Bergman, E. N. (1969). Simultaneous measurements of hepatic and portal venous blood flow in the sheep and dog. American Journal of Physiology 216, 946-952.

Kelly, J. M. \& McBride, B. W. (1990). The sodium pump and other mechanisms of thermogenesis in selected tissues. Proceedings of the Nutrition Society 49, 185-202.

Leng, R. A., Steel, J. W. \& Luick, J. R. (1967). Contribution of propionate to glucose synthesis in sheep. Biochemical Journal 103, 785-790.

Lindsay, D. B. \& Williams, R. L. (1971). The effect on glucose entry rate of abomasal protein infusion in sheep. Proceedings of the Nutrition Society 30,35A.

Lloyd, B., Burrin, J., Smythe, P. \& Alberti, K. G. M. M. (1978). Enzymic fluorometric continuous-flow assays for blood glucose, lactate, pyruvate, alanine, glycerol and 3-hydroxybutyrate. Clinical Chemistry 24, 1724-1729.

McBride, B. W. \& Milligan, L. P. (1985). Influence of feed intake and starvation on the magnitude of $\mathrm{Na}^{+}-\mathrm{K}^{+}$-ATPase-dependent respiration in duodenal mucosa of sheep. British Journal of Nutrition 53, $605-614$

Mangan, J. L. (1972). Quantitative studies on nitrogen metabolism in the bovine rumen. British Journal of Nutrition 27, 261-283.

Mercer, J. R. \& Miller, E. L. (1982). Effect of diet and infusion of volatile fatty acids into the rumen on the concentration of plasma free amino acids in sheep. British Journal of Nutrition 48, 519-526.

Moore, R. B. \& Kauffman, N. J. (1970). Simultaneous determination of citrulline and urea using diacetyl monoxime. Analytical Biochemistry 33, 263-272.

Prior, R. L., Huntington, G. B. \& Britton, R. A. (1981). Influence of diet on amino acid absorption in beef cattle and sheep. Journal of Nutrition 111, 2212-2222.

Reynolds, C. K. \& Huntington, G. B. (1988a). Partition of portal-drained visceral net flux in beef steers. 1. Blood flow and net flux of oxygen, glucose and nitrogenous compounds across stomach and posterior-stomach tissues. British Journal of Nutrition 60, 539-551.

Reynolds, C. K. \& Huntington, G. B. (1988b). Partition of portal-drained visceral net flux in beef steers. 2. Net flux of volatile fatty acids, D- $\beta$-hydroxyl butyrate and L-lactate across stomach and post-stomach tissues. British Journal of Nutrition $\mathbf{6 0}, 553-562$.

Reynolds, C. K., Huntington, G. B., Tyrell, H. F. \& Reynolds, P. J. (1986). Splanchnic tissue and whole animal oxygen consumption by lactating Holstein cows. Journal of Dairy Science 69, Suppl. 1, 193.

Sakata, T. \& Tamata, H. (1978). Rumen epithelium cell proliferation accelerated by propionate and acetate. Journal of Dairy Science 62, 49-52.

Schelling, G. T., Hinds, F. C. \& Hatfield, E. E. (1967). Effect of dietary protein levels, amino acid supplementation and nitrogen source upon the plasma free amino acid concentrations in growing lambs. Journal of Nutrition $\mathbf{9 2}$, 339-347.

Seal, C. J., Sarker, A. \& Parker, D. S. (1989). Rumen propionate production rate and absorption of fermentation end-products into the portal vein of forage- and forage-concentrate-fed cattle. Proceedings of the Nutrition Society 48, 143A. 
Smith, N. E. \& Baldwin, R. L. (1974). Effects of breed, pregnancy and lactation on weight of organs and tissues in dairy cattle. Joumal of Dairy Science 57, 1055-1060.

Sniffen, C. J. \& Jacobson, D. R. (1975). Net amino acid absorption in steers fed alfalfa hay cut at two stages of maturity. Journal of Dairy Science 58, 371-385.

Stevens, C. E. \& Stettler, B. K. (1966). Factors affecting the transport of volatile fatty acids across rumen epithelium. American Journal of Physiology 210, 365-372.

Sutton, J. D. (1985). Digestion and absorption of energy substrates in the lactating cow. Journal of Dairy Science 68, 3376-3393.

Symonds, H. W. \& Baird, G. D. (1973). Cannulation of a hepatic vein, the portal vein and a mesenteric vein in the cow and its use in the measurement of blood flow rates. Research in Veterinary Science 14, $267-269$.

Tagari, H. \& Bergman, E. N. (1978). Intestinal disappearance and portal blood appearance of amino acids in sheep. Journal of Nutrition 108, 790 803

Ulyatt, M. J., Whitelaw, F. G. \& Watson, F. G. (1970). The effect of diet on glucose entry rates in sheep. Joumal of Agricultural Science, Cambridge 75, 565-570.

Van Maanen, R. W., Herbein, J. H., McGilliard, A. D. \& Young, J. W. (1978). Effects of monensin on in vivo rumen propionate production and blood glucose kinetics in cattle. Journal of Nutrition 108, 1002-1007.

Veenhuizen, J. J., Russell, R. W. \& Young, J. W. (1988). Kinetics of metabolism of glucose, propionate and $\mathrm{CO}_{2}$ in steers as affected by injecting phlorizin and feeding propionate. Journal of Nutrition 118, 1366-1375.

Webster, A. J. F., Osumi, P. O., White, F. \& Lingram, J. F. (1975). The influence of food intake on portal blood flow and heat production in the digestive tract of sheep. British Journal of Nutrition 34, 1366-1375.

Weekes, T. E. C. \& Webster, A. J. F. (1975). Metabolism of propionate in the tissues of the sheep gut. British Journal of Nutrition 33, 425 438.

Weighart, M., Slepetis, R., Elliot, J. M. \& Smith, D. F. (1986). Glucose absorption and hepatic gluconeogenesis in dairy cows fed on diets varying in forage content. Journal of Nutrition 116, 839-850.

White, R. G., Steel, J. E., Leng, R. A. \& Luick, J. R. (1969). Evaluation of three isotope-dilution techniques for studying the kinetics of glucose metabolism in sheep. Biochemical Journal 114, 203-214.

Wilton, J. C. (1990). The effect of ammonia upon the metabolism of carbohydrates and amino acids in the liver of growing steers offered silage. PhD Thesis, University of Reading.

Windmueller, H. G. \& Spaeth, A. E. (1978). Identification of ketone bodies and glutamine as the major respiratory fuels in vivo for postabsorptive rat small intestine. Journal of Biological Chemistry 253, 69-76.

Windmueller, H. G. \& Spaeth, A. E. (1980). Respiratory fuels and nitrogen metabolism in vivo in small intestine of fed rats. Quantitative importance of glutamine, glutamate and aspartate. Journal of Biological Chemistry 225 , $107-112$.

Wolff, J. E., Bergman, E. N. \& Williams, H. H. (1972). Net metabolism of plasma amino acids by liver and portaldrained viscera of fed sheep. American Journal of Physiology 223, 438-446.

Yost, W. M., Young, J. W., Schmidt, S. P. \& McGilliard, A. D. (1977). Gluconeogenesis in ruminants : propionic acid production from a high-grain diet fed to cattle. Journal of Nutrition 107, 2036-2043. 